\title{
THE PLIO-PLEISTOCENE BOUNDARY IN SOUTHEAST SPAIN: A REVIEW
}

\author{
T. Bardají,* J.L. Goy,† P.G. Silva,† C. Zazo, N.A. Mörner,§ \\ L. Somoza, ๆ C.J. Dabrioll and J. Baena** \\ *Departmento Geología, Universidad Alcalá de Henares, 28871 Madrid, Spain \\ $\nmid$ Departmento Geología, Universidad Salamanca, 37008 Salamanca, Spain \\ $\ddagger$ Departmento Geología, Museo Nal. Ciencias Nat. C.S.I.C. Jose Gutierrez Abescal, 28006 Madrid, Spain \\ $\S$ Paleogeophysics and Geodynamics, S-1069l Stockholm, Sweden \\ qI.T.G.E. Rios Rosas, 23, 28003 Madrid, Spain \\ IIDepartmento Estratigrafia, Facultad Geologí, Universidad Complutense, 28040 Madrid, Spain \\ **Av. Brasilia, 21, 28018 Madrid, Spain
}

\begin{abstract}
The Plio-Pleistocene boundary in the Mediterranean region has been defined by the entry of the so-called 'northern guests'. The absence of this characteristic cold fauna in the sedimentary record of littoral marine basins in SE Spain has led to the local establishment of this boundary by other means. Most outcropping upper Pliocene and Pleistocene marine sediments in this area have a very shallow character, resulting in the absence of the planktonic foraminiferal assemblages that characterize the upper Pliocene. As a result the only means of deternining this boundary has been through regional correlation, detailed mapping and sedimentological analysis, as well as palaeomagnetism.

After

studies were carried out in differen

boundary (Aguirre and Pasini, 1985), we conclude that this boundary does not bear any climatic, environmental or tectonic signature. The changes in most of these basins seem to occur either before or after
\end{abstract}

\section{INTRODUCTION}

The Plio-Pleistocene boundary in the littoral Mediterranean basins of Southeast Spain has been traditionally defined in relation to some macrofaunal species and also to the presence of regressive sedimentary facies. The shallow character of the deposits has resulted in the complete absence of the characteristic upper Pliocene Globorotalia inflata biozone.

The presence of Strombus coronatus, Glycymeris bimaculata and Pecten jacobaeus, among others, has always been reported as characterizing the uppermost Pliocene in these basins. When no fauna are found, the boundary has been defined by the presence of a strong regressive trend in the sedimentary record, which was supposed to represent the beginning of the Pleistocene. However the tectonic activity which occurred in this Eastern Betic area precludes the use of a generalized and coeval regressive trend as an indicator of the climatic deterioration atributed to the beginning of the Quaternary.

Different basins have been studied from several points of view: sedimentological analysis, detailed mapping, regional correlation of outcropping sediments, and palaeomagnetism where the outcrop conditions were suitable for the application of this method.

\section{THE PLIO-PLEISTOCENE RECORD IN THE EASTERN BETICS: STATE OF THE ART}

The first regional type sequence for the Pliocene in
Southeastern Spanish basins was recorded by Montenat (1973). This author distinguished three main Pliocene units: Pliocene 1 (P.I: grey-blue marls); Pliocene II (P.II: yellow calcarenites) and Pliocene 3 (P.3: variegated marls and lacustrine limestones). The Early-Middle Pliocene age of P.l was established from the microfaunal assemblage of Globorotalia crassaformis (N20 of Blow, 1969). The absence of characteristic microfauna in the P.II unit limited estimates of its age to inferences from its stratigraphpic position relative to the P.I unit, and correlations with the Globorotalia crassaformis-G. inflata biozones. The same applies to the P.3 unit, which was considered locally to represent the last Pliocene regressive event. Consequently, the Plio-Pleistocene boundary was placed at the top of this last unit (Montenat, 1973; Montenat et al., 1990).

This sedimentary sequence has been widely cited in studies of these basins, especially for the correlation of Quaternary deposits. Consequently, the end of the Pliocene has been considered to coincide with a widespread regression in the eastern Betics realm. In some basins (Almeria, Lower Segura Basin, Fig. 1) this regressive trend was correlated with a lagoonal event that occurs above the Upper Pliocene yellow calcarenitic unit (Zazo, 1979; Baena, 1983a, b; Goy and Zazo, 1986). Similarly, in the Lower Segura Basin, this boundary was assumed (Montenat, 1973; Montenat et al., 1990) to correspond to a local fan-delta unit named the Segura Conglomerate. According to these authors, in the Campo de Cartagena-Mar Menor (Fig. 1) the Plio-Pleistocene boundary was represented by a terrestrial unit consisting 


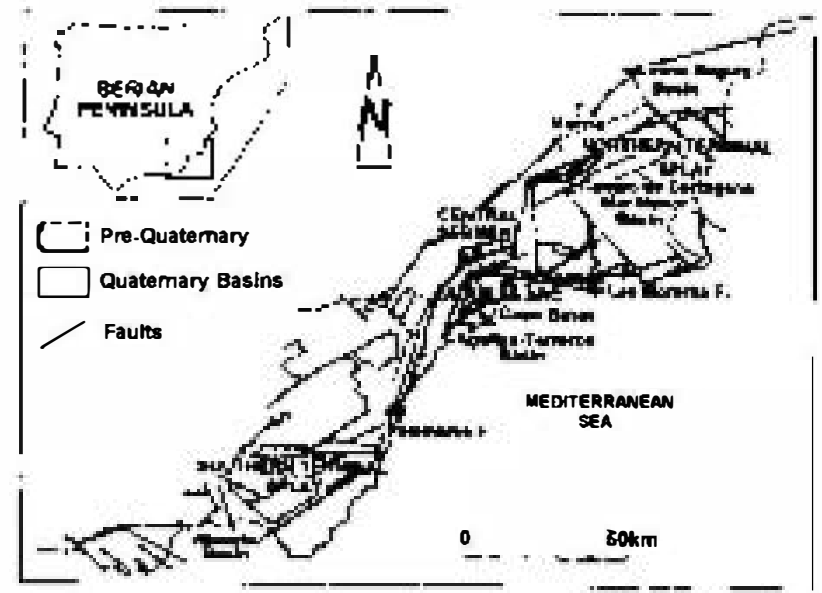

FIG. 1. Tectonic domains of the Eastem Betics Transcurrent Shear Zone and the location of the studied basins (after Bardaji et al., 1995a).

of red loams topped by a calcrete crust named the Sucina Formation. On the other hand, owing to the absence of similar facies in the Aguilas Arc basins (Fig. 1), this accepted end-Pliocene regression was interpreted as correlating with a shallow lumachellic conglomeratic level that unconformably overlies the P.II yellow calcarenites (Montenat et al., 1978; Bardají et al., 1986).

Bearing this 'chronological' arrangement in mind Goy et al. (1989) carried out preliminary palaeomagnetic measurements in the Almeria basin. The results gave a completely different view of this chronology: at least the uppermost part of the yellow calcarenites could be placed within the Early Pleistocene. Similarly, after palaeomagnetic measurements were carried out on the supposed Plio-Pleistocene Sucina Formation, the heterochronity of this unit became evident. This formation should be assimilated into an alluvial fan sequence that extended to the Middle Pleistocene (Somoza, 1989; Goy et al., 1989).

A more detailed palaeomagnetic study was carried out in basins in different tectonic settings within the eastern Betics (Bardají et al., 1993, 1994, 1995a, b). We can now state that the Plio-Pleistocene boundary (Olduvai upper palaeomagnetic inversion) almost always occurs within the formerly assumed Upper Pliocene yellow calcarenitic unit. This fact is important because, in terms of this evidence, the boundary does not have any climatic, environmental or tectonic implications within these southeastem Spanish basins.

\section{TECTONIC FRAMEWORK}

When attempting to define the Plio-Pleistocene boundary in Southeastern Spain, it is important to take into account the tectonic framework of this area. The genesis of sedimentary basins in Southeastern Spain has been largely related to tectonic activity along the Eastern Betics left-lateral shear zone (Montenat et al., 1987; Silva et al., 1993), which evolved in response to the continuous northward indentation of the Aguilas Arc (Fig. 1). Repeated and successive shifts in the regional stress field over short time-spans triggered large kinematic changes along the master faults of the transcurrent zone, causing major palaeogeographic changes.

This Plio-Pleistocene tectonic activity caused the redistribution of relief and the formation of sedimentary basins by generating a large subsiding corridor where most of the Quaternary basins are located. These changes defined the present morphostructural pattern of the transcurrent zone (Silva et al., 1993), which is characterized by different tectonic domains (Fig. 1): the Northem Terminal Splay, the Central Segment and the Southem Terminal Splay, in addition to the Aguilas Arc itself. The geodynamic behaviour of these domains differed strongly during the Plio-Pleistocene, depending on the behaviour of the main faults affecting each of them. In this sense, basin uplift, and the consequently regressive trend observed must be envisaged as a diachronous process which cannot be correlated with the onset of the climatic conditions that were supposed to characterize the beginning of the Quaternary (Silva et al., 1993; Bardají et al., 1995a, b).

\section{ENVIRONMENTAL CONDITIONS: DATA FROM THE SEDIMENTARY RECORD}

In order to obtain a more regional view of the evolution of Plio-Pleistocene environments, different basins have been studied in differing tectonic domains. Analysis of the facies present in basins located in each tectonic domain, indicates a different sedimentary evolution within each of them. Detailed cartography carried out together with sedimentological analyses has facilitated the correlation of deposits and the interpretation of the sedimentary environments (Baena, 1983a, b; Goy and Zazo, 1986, 1989; Goy et al., 1989, 1990; Dabrio et al., 1990, 1991; Bardají et al., 1993, 1994, 1995a, b).

\section{Lower Segura Basin}

This basin is located in the northernmost branch of the Northern Terminal Splay (Fig. 1). It contains an extensive sequence of Plio-Pleistocene deposits, being the locality in which the 'Pliocene' sequence was first defined. The sedimentary record of this basin contains the three classical 'Pliocene' facies: grey-blue marls, yellow calcarenites and variegated silts and marls. Their regional distribution, together with the sedimentological analyses of these facies has led us to interpret them as having been deposited in a transitional lagoon-barrier island environment (Somoza, 1989; Goy et al., 1989). In this model, the grey-blue marls correspond to an open marine environment, the yellow calcarenites to the barrier island facies and the variegated silts to the lagoonal facies. The continuous shift towards the sea of these three different sub-environments caused the superposition of the different facies, giving the impression of chronostratigraphic rather than lithostratigraphic units. Two gently unconformable transitional units have been distinguished in this basin (Somoza, 1989; Goy et al., 1989; Bardaji et al., 1995a, b, c): the Lower Segura Transitional Unit and the 
El Moncayo-El Molar Transitional Unit. A strong unconformity separates these units from the overlying Segura Conglomerates. The high energy character of this unit indicates a sudden and important palaeogeographic and environmental change in this basin, promoted by tectonics. The regional relationships between this last unit and Middle-Late Pleistocene marine terraces (Goy et al., 1989, 1990) makes it impossible to assign a PlioPleistocene age to this unit; it must therefore be of substantially younger age

\section{Campo de Cartagena-Mar Menor Basin}

This basin is located in the southem branch of the Northern Terminal Splay (Fig. 1). At present this basin is separated from the Lower Segura Basin by the Carrascoy Range, but formerly they constituted a wide, irregular and unique basin where an extensive lagoon-barrier island environment developed (Montenat, 1973; Somoza, 1989; Goy et al., 1989, 1990; Bardaji et al., 1995c). The facies present in this basin are consequently similar to those found in the Lower Segura Basin. Yellow calcarenites occur extensively in both basins, but the variegated silts and marls found in the Lower Segura Basin are replaced here by lacustrine limestones. Differences in the outcropping lithofacies led to the interpretation of two similar transitional environments, but with different depositional dynamics, along this wide Plio-Pleistocene basin. The sedimentary environment in the Campo de Cartagena-Mar Menor basin is dominated by an estuarine coastal plain, isolated by beach barrier systems with the consequent development of paludal lakes (Silva, 1994; Bardaji et al., 1995c). A similar regressive trend to that event in the Lower Segura Basin is observed in this basin. Nevertheless, sudden tectonically-induced progradations of the fluvial system are manifested as apparent rapid regressive episodes, followed by false transgressive episodes (Silva, 1994).

\section{Aguilas and Cope basins}

These basins are located within the Aguilas Arc structure (Fig. 1), and they both record similar PlioPleistocene sedimentary histories. The sedimentary record includes the characteristic yellow calcarenite facies, but here this represents a different environment. On the evidence of the sedimentary structures present these calcarenites must have been deposited in a wavedominated, shallow marine to sublittoral environment, (Montenat, 1973; Montenat et al., 1978, 1990; Goy et al., 1990; Dabrio et al., 1990). Sandy and gravelly lumachellic coastal facies and deeper marly sands and marls occur as lateral equivalents. These facies are unconformably overlain within these basins by fan-delta or beach conglomerates, with interbedded alluvial fan deposits; the record ends with the Tyrrhenian episodes (Bardaji et al., 1986, 1990, 1993, 1995a, b; Dabrio et al., 1990, 1991).

\section{Almeria Basin}

This basin is located in the Southern Terminal Splay (Fig. 1). The sedimentary record is quite similar to that found in the Aguilas Arc basins. Yellow marls and calcarenites must be interpreted also as having been deposited in a wave-dominated shallow marine environment, represented by deeper to shallower facies respectively. These deposits are separated by a strong unconformity from an overlying regressive delta unit (Baena, 1983a; Giner, 1983; Zazo and Goy, 1983; Postma, 1984; Bardaji et al., 1995a, b). The end of this regressive event is represented by a lagoon-beach barrier system (Bardají et al., 1995a, b) which grades laterally into terrestrial alluvial fan deposits. The later sedimentary sequence is followed by different marine terraces, which include the four Tyrrhenian episodes defined for the Southeast of Spain (Goy and Zazo, 1986; Hillaire-Marcel et al., 1986; Zazo et al., 1989).

\section{CHRONOLOGICAL CONTROL: THE FAUNAL AND PALAEOMAGNETIC RECORD}

The chronological framework has been established in terms of two criteria: faunal content and palaeomagnetic measurements. It should be noted that the characteristics of the outcropping sediments were not always suited to both kinds of analysis.

\section{Lower Segura Basin}

The presence of Globorotalia margaritae, G. puncticulata and $G$. crassafornis in the grey-blue marls allows us to ascribe this unit to the early-middle Pliocene. At the base of the variegated silts unit Montenat and Crussafont Pairó (1970) reported the appearance of Hipparium cf. crassum (MN14 of Mein, 1975), and Montenat and De Bruijn (1976) reported a rodent assemblage in these same deposits (Ruscynomis cf. europeus, Stephanomys cf. minor, Cricetus cf. barrieri, MN14-MN15 of Mein, 1975), indicating a Ruscinian (Early Pliocene) age. The appearance of Chlamys glabra in a calcarenitic horizon on top of this unit points to a significantly younger age, since this species usually appears in Spain during the Early Pleistocene (Bardají et al., 1995a, b, c). These faunal occurrences indicate, without any doubt, the heterochronous nature of the facies, and consequently the impossibility of correlating facies with age in this basin.

The palaeomagnetic record established in this sedimentary sequence provides a similar chronological perspective: the Olduvai upper transition occurs within the upper part of the yellow calcarenitic unit (Bardaji et al., 1993, 1994, 1995a, b). These data suggest that this transitional environment lasted from the Early Pliocene up to the Middle Pleistocene. 


\section{Campo de Cartagena Mar Menor Basin}

The lack of characteristic fauna and the difficulty of analyzing the entire sedimentary record in one section have thusfar impeded attempts to establish the succession of events for this basin. Nevertheless, correlation with the Guadalentin depression (Silva, 1994) and the results of some isolated palaeomagnetic analyses carried out in the littoral sector of the basin (Somoza et al., 1989; Goy et al., 1989) have helped in the establishment of a chronology. The sequence investigated rests unconformably on a thick sequence that includes characteristic Messinian microfauna (G. mediterranea, G. humerosa, $G$. accostaensis, Montenat, 1973; Larouziere, 1985) and the ostracod Peteraurila cf. musculus Aruta and Ruggieri on the top (Silva, 1994) that also belongs to this period. On the other hand, palaeomagnetic measurements carried out in the distal facies of the so called Sucina Formation (Somoza et al., 1989; Goy et al., 1989) include the Matuyama-Brunhes transition. These data indicate that the development of the transitional environment in this basin spans the entire Pliocene and most of the lower Pleistocene, as was the case in the Lower Segura Basin (Bardaji et al., 1995c).

\section{Aguilas Arc basins}

The assemblages of planktonic foraminifera reported for these basins (Montenat et al., 1978) include Globigerina bulloides, Globigerinoides obliquus, $G$. extremus, Globorotalia margaritae and Turborotalia obesa for the lower marly facies, indicating the Globorotalia margaritae biozone, followed upwards by the $G$. puncticulata biozone. The rest of the calcarenitic unit is assumed to represent the $G$. crassaformis biozone. The presence of Strombus coronatus, Glycymeris bimaculata and Flabellipecten alessii in the overlying lumachellic conglomerate was supposed to be representative of the late Pliocene.

Palaeomagnetic analyses carried out in the Cope Basin (Bardaji et al., 1993, 1995a, b) showed that the Olduvai upper reversal occurs within the uppermost part of the yellow calcarenitic unit, and the Matuyama-Brunhes within the overlying sequence of marine deposits. This chronology accords with the later presence of Strombus bubonius bearing episodes of deposition.

\section{Almeria Basin}

The only reports of microfauna in this basin have been by Baena (1983a, b), who found planktonic assemblages which permitted definition of the $G$. crassaformis and $G$. puncticulata biozones. This palaeontological evidence reveals that sedimentation of the yellow calcarenite unit was younger than Early Pliocene. Overlying clastic sediments (deltas and beaches) do not bear any characteristic fauna. As was the case in the Aguilas Arc Basins, the micropalaeontological analyses could only be carried out in the deeper marly facies. This means that the whole regressive sequence, with its shallower character, cannot be dated by biostratigraphic means. As a result, the only reliable means of establishing a chronological framework for these facies was again by palaeomagnetism. The results obtained for this basin show that the Olduvai upper inversion must have occurred in the hiatus separating the yellow calcarenite unit from the overlying clastic deposits; the Jaramillo event is present within the lagoonal deposits formerly thought to represent the PlioPleistocene boundary (Bardaji et al., 1995a, b). This chronology is supported by the relationship of these deposits to Strombus bubonius bearing marine terraces.

\section{DISCUSSION}

The chronological arrangement of the sedimentary units for each basin, together with their palaeontological content, is included in Table 1.

TABLE 1. Chronostratigraphic arrangement of Plio-Pleistocene sedimentary sequences of southeastem Spain (modified after Bardají et al., 1995a)

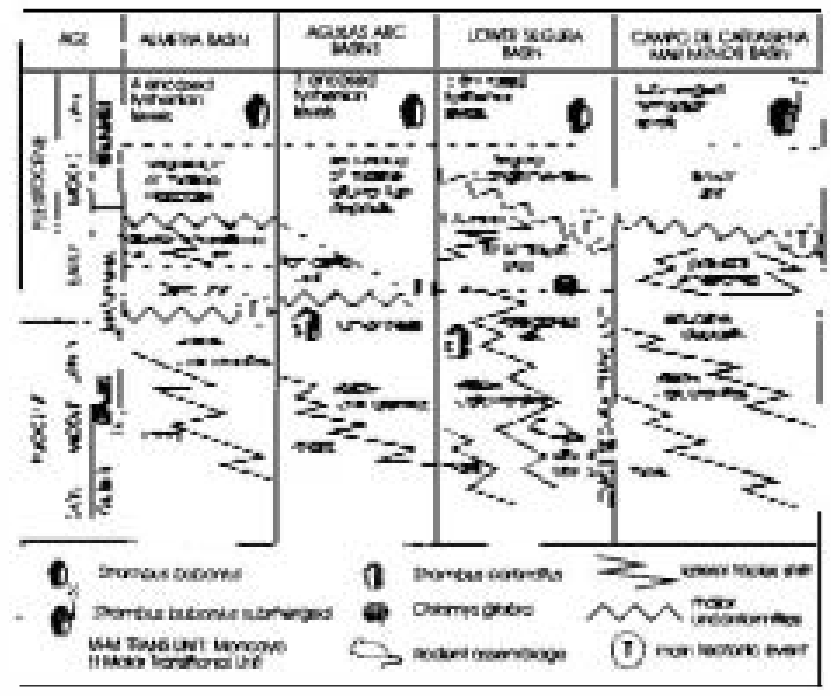

A preliminary correlation with the palaeomagnetic scale is also included, based in the results obtained for the Almeria, Cope and Lower Segura Basins. Major regressive trends and unconformities are always related to tectonic events.

On the basis of this new evidence we may conclude that, in all of these basins, the chronology cannot be established in terms of lithostratigraphic units, since these have been shown to be heterochronous. It is impossible to carry out specific biostratigraphic analyses because of the shallow character of the facies, and this implies that the only method of obtaining a more realistic chronological framework is by means of palaeomagnetism.

From the palaeomagnetic results obtained for basins located in different tectonic realms, and accepting the present official Plio-Pleistocene boundary (Aguirre and Pasini, 1985), we conclude that the Olduvai upper transition always occurs within the uppermost part of the yellow calcarenite facies. This means that this boundary does not represent any change either in sedimentary environment or in climatic conditions. 
Sudden and strong palaeogeographic changes occur later in time, but not simultaneously within the different basins. This indicates that these changes have been tectonically induced, and that the diachronous regressive trend observed in this area cannot be related in any way to a climatic influence.

The reason for the absence of Atlantic cold fauna in this littoral zone is unknown at present. Could it be related to palaeocurrent patterns? Was the climate in Southeast Spain different from that recorded in other western Mediterranean regions? There are many unresolved questions that may be answered by further research. What appears certain is that at $1.80 \mathrm{Ma}$ the southeastem Spanish coast did not undergo any drastic change in environmental conditions, as evidenced by sedimentary, palaeontologic and palaeomagnetic records. Comparisons with other neighbouring terrestrial basins, and with other littoral basins in southwest Spain must be carried out in order to obtain a more regional view of the Plio-Pleistocene evolution of this area. We must also bear in mind that southem Spain, because of its transitional character, is a key area for the establishment of relationships between the Atlantic and Mediterranean regions.

\section{ACKNOWLEDGEMENTS}

This research was supported by Spanish DGICYT Projects PB92-282 and PB92-0023.

\section{REFERENCES}

Aguirre, E. and Pasini, G. (1985). The Pliocene-Pleistocene boundary. Episodes, 8, 116-120.

Baena, J. (1983a). Cartografia y Memoria del Né́geno y Cuaternario Mapa Geológico de España (Plan MAGNA) Escala 1:50.000. $2^{a}$ Serie, Hoja (23-43), Almeria.

Baena, J. (1983b). Cartografia y Memoria del Né́geno y Cuaternario Mapa geologico de España (Plan MAGNA) Escala 1:50.000. $2^{A}$ Serie, Hoja (22-44), Roquetas.

Bardají, T., Civis, J., Dabrio, C.J., Goy, J.L., Somoza, L. and Zazo, C. (1986). Geomorfología y estratigrafía de las secuencias marinas y continentales cuaternarias de la Cuenca de Cope (Murcia). In: Lopez Bermudez and Thornes (eds), Estudios dobre geomorfologia del sur de Espana. Comm. Meas. Theory and Applic. in Geomorpholoqy, Int. Geogr. Union, pp. 11-16. Universidades de Murcia y Bristol.

Bardají, T., Dabrio, D.J., Goy, J.L., Somoza, L. and Zazo, C. (1990). Pleistocene fan deltas in south-eastern Iberian peninsula: sedimentary controls and sea level changes. In: Colella and Prior (eds), Coarse grained Deltas. Spec. Publs. Int. Ass. Sediment., 10, 129-151.

Bardají, T., Dabrio, C.J., Goy, J.L., Mörner, N.A., Silva, P.G., Somoza, L. and Zazo, C. (1993). Major Quaternary depositional changes in Eastern Betics shallow marine environments (SE Spain). $3^{a}$ Reunion de Cuatemario Ibérico, Coimbra (Portugal), Septiembre, 1993, p. 142.

Bardají, T., Goy, J.L., Mörner, N.A., Zazo, C.. Silva, P.G., Somoza, L., Dabrio, C.J. and Baena, J. (1994). Plio-Pleistocene sedimentary record in transitional environments (Lower Segura Basin, Eastern Betics, SE Spain). Convegno sul tema Il significato del Villafranchiano nella stratigrafia del Plio-Pleistocene, Peveragno (Italy), June, 1994.

Bardají, T., Goy, J.L., Mörner, N.A., Zazo, C., Silva, P.G., Somoza, L., Dabrio, C.J. and Baena, J. (1995). Towards a Plio--Pleistocene chronostratigraphy in Eastern Betic Basins (SE Spain). Geodynamica Acta, 8, 112-126.

Bardají, T., Goy, J.L., Silva, P.G., Mörner, N.A., Zazo, C., Baena, J. and Dabrio, C.J. (1995b). Plio-Pleistocene

SE Spain. Terra Nostra, Abstracts XIV NQUA Congress, Berlin.
Bardají, T., Silva, P.G., Goy, J.L., Mörner, N.A., Zazo, C., Somoza, L., Dabrio, C.J. and Baena, J. (1995). Unchanging environmental conditions during the 'Villafranquian' time-span in littoral basins (Eastern betics, SE Spain). Il Quatemario, 8, 383-390.

Blow, W.H. (1969). Late middle Eocene to recent planktonic foraminiferal biostratigraphy. Proc. Ist. Int. Conf. Plank. Micr. Geneve, 1, 199-422.

Dabrio, C.J., Zazo, C., Goy, J.L., Santisteban, C., Bardají, T. and Somoza, L. (1990). Neogene and Quaternary fan-delta deposits in south-eastern Spain, Field Guidebook, Il Fan-Delta Workshop, Murcia (Spain), 1990. Cuademos de geología Ibérica, (Madrid, 1991). 15, 327-400.

Dabrio, C.J., Bardají, T., Zazo, C. and Goy, J.L. (1991). Effects of sealevel changes on a wave-worked Gilbert type delta (late Pliocene, Aguilas Basin, SE Spain). Cuademos de Geologia Ibérica, 15, $103-$ 107.

Giner, P. (1983). Cartografia y Memoria del Terciario. Mapa Geologico de Espana (Plan MAGNA) Escala 1:50.000, $2^{\circ}$ Serie, Hoja (23-44), El Cabo de Gata e Isla de Alborán.

Goy, J.L. and Zazo, C. (1986). Synthesis of the Quatemary in the Almeria littoral, neotectonic activity and its morphologic features, western Betics (Spain). Tectonophysics, 130, 259-270.

Goy, J.L. and Zazo, C. (1989). The role of neotectonics in the morphologic distribution of the Quatemary marine and continental deposits of the Elche Basin, south-east Spain. Tectonophysics, 163, 219-225.

Goy, J.L., Zazo, C., Somoza, L., Dabrio, C.J. and Bardají, T. (1989). Litoral Beticas Orientales (Alicante, Murcia, Almeria). In: Zazo, C., Dabrio, C.J. and Goy, J.L. (eds), Libro guia, Excursion B-1: Litoral Mediterráneo. $2^{a}$ Reunión del Cuatemario lbérico, Madrid.

Goy, J.L., Zazo, C., Somoza, L. and Dabrio, C.J. (1990). Evolución paleogeográfica de la Depresion de Elche-Cuenca del Bajo Segura durante el Pleistoceno. Estudios Geológicos, 46, 237-244.

Hillaire-Marcel, Cl., Carro, O., Causse, Ch., Goy. J.L. and Zazo, C. (1986). Th-U dating of Strombus bubonius bearing marine terraces in south-eastern Spain. Geology, 14, 613-618.

Larouziere, F. (1985). Etude tectono-sedimentaire et magmatique des basins nóogènes d'Hinojar et de Mazarron (Cordillères Bétiques Internar, Espagne). Thése Univ. Paris, 6, 316.

Mein, P. (1975). Report on activity of the RCMNS Working Group, (1971-1975), pp. 78-80. Bratislava.

Montenat, Ch. (1973). Les formations néogènes et quaternaires du Levant espagnol (Provinces d'Alicante et de Murcia). Thése Sci. Univ. Orsay, p. 1170.

Montenat, Ch. and Crussafont Pairó, M. (1970). Découverte des Mammifères dans le Néogène et le Pléistocène du Levant espagnol (Provinces d'Alicante et de Murcia). C.R. Acad. Sc. Paris,, 270, 2434--2437.

Montenat, Ch. and De Bruijn, H. (1976). The Ruscinian rodent faunule from La Juliana (Murcia): its implication for the correlation of continental and marine biozones. Proceedings of the Koninklijke Nederlanse Akademic van Wetenschappen, Amsterdam, series B, v.79 (4)

Montenat, Ch., De Reneville, P. and Bizon, G. (1978). Le Néogène des environs d'Aguilas (provinces de Murcia et d'Almeria), Cordillères Bétiques, Espagne. Bull. Mus. natn. Hist. nat., Paris 3 e ser., 511, jant'-févr. Sciences de la Terre, 68, 37-54.

Montenat, Ch., Ott d'Estevou, Ph. and Masse, P. (1987). Tectonicsedimentary characters of the Betic Neogene basins evolving in a crustal transcurrent shear zone (SE Spain). Bull. Centres Rech. Explor. Prod. Elf-Aquitaine, 11, 1-22.

Montenat, Ch., Ott d'Estevou, Ph. and Coppier, G. (1990). Les bassins néogènes entre Alicante et Cartagena. In: Montenat, $\mathrm{Ch}$. (coord.), Les Bassins Neogenes du Domain Betique Criental (Espagne). Doc. et Trav. I.G.A.L., 12-13, 313-368.

Postma, G. (1984). Mass-flow conglomerates in a submarine canyon: Abrioja Fan-Delta, Pliocene, South-east Spain. In: Koster, D.H. and Steel, R.J. (eds), Sedimentology of Gravels and Conglomerates, Canadian Society of Petroleum Geologists, 10, 237-258.

Silva, P.G. (1994). Evolución geodinámica de la Depresión del Guadalentín desde el Mioceno superior hasta la actualidad: Neotectónica y Geomorfología. Tésis Doctoral, Universidad Complutense de Madrid, 642 pp.

Silva, P.G., Goy, J.L., Somoza, L., Zazo, C. and Bardají, T. (1993). Landscape response to strike-slip faulting linked to collisional settings: Quaternary tectonics and basin formation in the Eastem Betics, south-eastern Spain. Tectonophysics, 224, 289-303. 
Somoza, L. (1989). El Cuaternario litoral entre Cabo de Palos y Guardamar del Segura (Murcia-Alicante). Evolución qeodinámica en relación con las variaciones del nivel del mar. Tésis Doctoral, Universidad Complutense Madrid, p. 352.

Somoza, L., Zazo, C., Goy, J.L. and Mömer, N.A. (1989). Estudio geomorfoĺgico de secuencias de abanicos aluviales cuatemarios (Alicante-Murcia, Espana). Cuatemario y Geomorfologia, 3, 73-82.

Zazo, C. (1979). El problema del limite Plio-Pleistoceno en el litoral S y SE de Espana. In: Zazo, C. and Aguirre, E. (eds), Reunión del Grupo Espanol del Limite Neógeno-Cuatemario. Trab. sobre NeógenoCuatemario, 9.
Zazo, C. and Goy, J.L. (1983). Cartografía y Memoria del Cuaternario. Mapa Geológico de España (Plan MAGNA) Escala 1:50.000, $2^{\circ}$ Serie, Hoja (23-44), El Cabo de Gata e Isla de Alborán.

Zazo, C., Goy, J.L., Somoza, L. and Bardají, T. (1989). Recent Quaternary marine levels in Peninsular Spain, State of knowledge and discussion. In: Zazo, C. (ed.), Late Quatemary Sea-Level Changes in Spain, Trabajos sobre Neogeno-Cuatemario, 10, 7-31. 